Hikmah: Journal of Islamic Studies, 16 (1), 2020, 1-15

http://journal.uinjkt.ac.id/index.php/HIKMAH

DOI: 10.47466/hikmah.v16i1.164 | P-ISSN. 2088-2629, E-ISSN. 2581-0146

\title{
A PROPORTIONAL ALLOCATION OF FORMATIVE AND SUMMATIVE ASSESSMENT: A QUEST OF SHAPING AN EFFECTIVE ASSESSMENT POLICY
}

\author{
Sabilil Muttaqin \\ Flinders University-Adelaide, South Australia \\ syiamok@gmail.com
}

\begin{abstract}
This paper outlines and discusses most of the literatures on formative and summative assessment. It considers some of the key features of both formative and summative assessment as a means of evaluating teaching and learning processes. This study suggests that both types of assessment should be proportionally designed and aligned with learning goals. More importantly, this study proposes three key aspects of assessment that should be considered in designing effective assessment policy: (a) assessment forms an integral part of planning, assessing, and reporting, (b) the use of assessment as a means to monitor the progress of student learning and achievement, (c) assessment as a tool to determine the effectiveness of teaching. The three aspects of assessment policy can help educational leaders to design a proportional formative and summative assessment for an effective assessment policy.
\end{abstract}

Keywords: Assessment; Formative; Summative; Learning

\begin{abstract}
Abstrak
Artikel ini memaparkan dan mendiskusikan literatur-literatur tentang penilaian formatif dan sumatif. Artikel ini juga menyuguhkan gambaran penting penilaian formatif dan sumatif sebagai alat evaluasi pengajaran dan proses pembelajaran. Kajian ini menemukan bahwa kedua jenis penilaian tersebut harus didesain secara proporsional dan harus sejalan dengan tujuan pembelajaran. Lebih penting lagi, kajian ini menawarkan tiga aspek penting yang harus dipertimbangkan dalam merancang kebijakan penilaian yang efektif: (a) penilaian harus membentuk sebuah bagian integral dari perencanaan, penilaian dan pelaporan, (b) penggunaan penilaian sebagai alat untuk memonitor progress pembelajaran siswa dan pecapaiannya, (c) penilaian sebagai alat untuk menentukan efektivitas mengajar. Tiga aspek kebijakan penilaian tersebut dapat membantu pemimpin pendidikan untuk merancang penilaian formatif dan sumatif yang proporsional untuk sebuah kebijakan penilaian yang efektif.
\end{abstract}

Kata Kunci: Penilaian; Formatif; Sumatif; Pembelajaran 


\section{INTRODUCTION}

Assessment policy is an important factor that can contribute significantly to the effectiveness of teaching and learning. In many cases, the assessment policy can benefit the educational system of an institution where the policy is administered. Thus, developing a comprehensive and integral assessment policy is highly essential. The comprehensiveness can be seen through the thorough covering of the significant aspects of an assessment policy, in terms of indicating the purpose, the broad philosophy, the principles, the approach, the stakeholders, and the procedures. More importantly, the policy should be an integral system that links assessment with teaching and learning, as well as different roles of stakeholders.

One of the most important aspects of assessment policy is appointing the right choice of assessment types; between formative and summative. Formative and summative assessment have become one of the major topics discussed in the literature. Some scholars believe that formative assessment should be applied in order to enhance learning achievement. However, other scholars believe that summative assessment is an essential tool to measure students learning achievement. This notion, to some extent, has triggered the occurrence of certain tendency toward one out of the two opinions concerned. However, formative and summative assessment are two essential elements that can contribute significantly to the success of learning process. In this regard, any judgment on the effectiveness of formative and summative assessment should consider its role and implication to the learning process. By doing so, a more comprehensive perspective will be achieved.

\section{METHOD}

This paper will initially identify the main features of formative and summative assessment as well as comparing it. Then, it will elaborate some discussion concerning the use of formative and summative assessment in the learning process. Following that, this article will review the key principles of assessment concerning curriculum and instructional process which: (a) forms an integral part of the planning/assessment/reporting cycle, (b) monitors the progress of student learning and achievement, (c) determines the effectiveness of teaching, (d) utilizes a variety of methods, (e) should be in a context that is relevant and motivating to students, (f) informs curriculum and assessment review. To put the paper into perspective, it will initially provide a brief review and discuss all the key principles in a wider context. Then, the discussion will be focused on three main aspects concerning the role of formative and summative assessment, the contribution of assessment to teaching and learning, and the role and contribution of students to assessment. Subsequently, this paper 
will try to signify a perspective on formative and summative assessment in regard to its nature, role, and implication to learning process before giving the conclusion.

\section{RESULTS AND DISCUSSION}

\section{The Nature of Formative and Summative Assessment}

Before further steps into discussing formative and summative assessment, it is important to have a clear perspective of the two concepts mentioned. Some literatures used different terms to illustrate the two concepts mentioned. The term formative assessment will be understood as classroom activities used by teachers and students in order to gather information that will be employed as feedback to modify the teaching and learning activities, assessment for learning or classroom assessment. ${ }^{1}$ While summative assessment is perceived as large scale standardized assessment which may include mid-term and final test. Summative assessment is also called assessment of learning. ${ }^{2}$ At least there are four aspects of formative assessment and summative assessment which are different in nature: the purpose of assessment, the time of assessment, the use of assessment information, and the type of assessment. ${ }^{3}$

In terms of the purpose of the assessment, formative assessment is meant to monitor and guide the ongoing learning process. ${ }^{4}$ Teachers use the assessment to collect data of students' learning progress in conjunction with learning targets that have been set up. It includes questioning whether the learning process is leaning toward the targets or it is not. ${ }^{5}$ In some cases, based on the data, teachers might alter their teaching strategies when the current strategy is considered as ineffective to achieve the learning targets. ${ }^{6}$ In contrast,

${ }^{1}$ Paul Black \& Dylan Wiliam, “Assessment and Classroom Learning, Assessment in Education”, Abingdon: Mar 1998. Vol. 5, Iss. 1, p. 7-74; Richard J. Stiggins, Student - Centered Classroom Assessment. Second Edition, (New Jersey: Merrill Prentice Hall, 1997), p. 1-521.

${ }^{2}$ Richard J. Stiggins, "Student - Centered Classroom Assessment. Second Edition”, p. 521; Anthony J. Nitko and Susan Brookhart, Educational Assessment. Fifth Edition (New Jersey: Pearson Prentice Hall, 2007), p. 1-576; Euguenia Peterson \& M. Siadat, "Combination of formative and summative assessment instruments in elementary algebra classes: A prescription for success”, Journal of Applied Research in the Community College, (Stillwater : New Forums Press), 2009), p. 92-102

${ }^{3}$ Peter W. Airasian and Michael K. Russell, Classroom Assessment: Concepts and Applications. (New York: McGraw-Hill Higher Education, 2008), p. 1-412 ; Richard J. Stiggins, "Student - Centered Classroom Assessment. Second Edition", p. 521; Boyle \& Marie, 2013).

${ }^{4}$ Richard J. Stiggins, "Student - Centered Classroom Assessment. Second Edition”, p. 1-521; Nitko and Brookhart, 2007; Peter W. Airasian and Michael K. Russell, Classroom Assessment: Concepts and Applications (New York: McGraw-Hill Higher Education, 2005), p. 234

${ }^{5}$ Euguenia Peterson \& M. Siadat, "Combination of formative and summative assessment instruments in elementary algebra classes: A prescription for success", Journal of Applied Research in the Community College, (Stillwater: New Forums Press), 2009), p. 92-102.

${ }^{6}$ Richard J. Stiggins, "Student - Centered Classroom Assessment. Second Edition”, p. 1-521; Anthony J. Nitko and Susan Brookhart, Educational Assessment. Fifth Edition (New Jersey: Pearson Prentice Hall, 2007), p. 1-576; Peter W. Airasian and Michael K. Russell, Classroom Assessment, 2005, p. 234 
summative assessment is employed as a tool to measure and judge the success of learning. ${ }^{7}$ By administering this type of assessment, teachers would be able to understand whether the students have achieved the learning targets or have not. Moreover, this will allow teachers to see how some students perform better than others. ${ }^{8}$

The difference of assessment purposes, to some extent, leads to the different time of conducting the assessment. Formative assessment, which is meant to monitor and guide the learning process, is conducted during the process of learning. It is mainly because formative assessment emphasizes on continues observation for students learning progress and evaluation. ${ }^{9}$ On the contrary, summative assessment is conducted in the end of the learning process. It tends to be a single-time test administered to all students because the assessment is intended to judge the success of the learning process, even to grade the students. ${ }^{10}$ Therefore, the best time to do it is when the learning process is finished.

Another significant difference between the two assessments is the use of information obtained from the assessment. For summative assessment, the information resulted is designed to measure the overall success of learning process, in terms of grading, placing, and promoting the students. ${ }^{11}$ On the other hand, the information obtained from formative assessment is used to improve and change learning process when it is still in process, an ongoing assessment. Moreover, the information is intended to be used as the basic information to close the gap between learning targets and students' achievement progress. ${ }^{12}$

Furthermore, the three aspects mentioned affect the use of assessment techniques in both assessments. The summative assessment tends to use some structured and formal tests such as projects and paper pencil tests. Whereas formative assessment might use other types

7 Peter W. Airasian and Michael K. Russell, Classroom Assessment, p. 234; W. Harlen \& M. James, "Assessment and learning: Differences and relationships between formative and summative assessment". Assessment in Education. Nov. 1997, p. 4, 3.

${ }^{8}$ Richard J. Stiggins, "Student - Centered Classroom Assessment. Second Edition”, p. 1-521; Anthony J. Nitko and Susan Brookhart, Educational Assessment. Fifth Edition (New Jersey: Pearson Prentice Hall, 2007), p. 1-576; Peter W. Airasian and Michael K. Russell, Classroom Assessment, 2005, p. 234.

${ }^{9}$ Richard J. Stiggins, “Student - Centered Classroom Assessment. Second Edition”, p. 1-521.

${ }^{10}$ Richard J. Stiggins, "Student - Centered Classroom Assessment. Second Edition", p. 1-521; Airaisian, 2005; Anthony J. Nitko and Susan Brookhart, Educational Assessment. Fifth Edition (New Jersey: Pearson Prentice Hall, 2007), p. 1-576; Peter W. Airasian and Michael K. Russell, Classroom Assessment: Concepts and Applications. (New York: McGraw-Hill Higher Education, 2008), p. 1-412.

${ }^{11}$ Richard J. Stiggins, "Student - Centered Classroom Assessment. Second Edition”, p. 1-521; Nitko and Brookhart, 2007; Peter W. Airasian and Michael K. Russell, Classroom Assessment: Concepts and Applications. (New York: McGraw-Hill Humanities, 2005), p. 1-448

${ }^{12}$ Richard J. Stiggins, "Student - Centered Classroom Assessment. Second Edition”, p. 1-521; Anthony J. Nitko and Susan Brookhart, Educational Assessment. Fifth Edition (New Jersey: Pearson Prentice Hall, 2007), p. 1-576; Airaisian, 2005; Ecclestone, 2010). 
of techniques that are less formal and less structured such as informal observation, homework, and pupil questions. ${ }^{13}$

\section{Putting formative and Summative Assessment Into Perspective}

There has been an extensive effort in the literature to incorporate more use of formative assessment in the learning process. ${ }^{14}$ One of the reasons is that formative assessment is an ongoing assessment system that can be tailored and adjusted towards the learning targets according to the assessment users' necessities and capabilities. ${ }^{15}$ Specifically, a well-designed formative assessment will provide a clearer picture for both students and teachers about their current learning state. ${ }^{16}$ By doing so, they will have the opportunity to evaluate their learning activities in conjunction with educational and vocational learning objectives, which may contribute to the success of students in their educations and lives. ${ }^{17}$ One of the evidences that supports this conception is some research reviewed by Black and Wiliam which showed that improvement in classroom assessment can make a strong contribution to improvement in learning. ${ }^{18}$

Another reason of this shift is that the role of summative assessment, which is grading and judging students, has been too dominant. Therefore, there should be more focus on the formative role of assessments which are evaluating, directing, and motivating. ${ }^{19}$ Furthermore, summative assessment could not give the right picture of students' achievements because the learning process could not be simply measured by the result of paper-pencil based tests. ${ }^{20}$ Rather, the assessment should be linked closely to the learning

\footnotetext{
${ }^{13}$ Richard J. Stiggins, "Student - Centered Classroom Assessment. Second Edition”, p. 1-521; Anthony J. Nitko and Susan Brookhart, Educational Assessment. Fifth Edition (New Jersey: Pearson Prentice Hall, 2007), p. 1-576; Airaisian, 2005; Euguenia Peterson \& M. Siadat, "Combination of formative and summative assessment instruments in elementary algebra classes: A prescription for success”, Journal of Applied Research in the Community College, (Stillwater : New Forums Press), 2009), p. 92-102.

${ }^{14}$ Paul Black \& Dylan Wiliam, “Assessment and Classroom Learning, Assessment in Education”, Abingdon: Mar 1998. Vol. 5, Iss. 1, p. 7-74; Richard J. Stiggins, "Student - Centered Classroom Assessment. Second Edition”, p. $1-521$.

${ }^{15}$ Paul Black \& Dylan Wiliam, “Assessment and Classroom Learning, Assessment in Education”, Abingdon: Mar 1998. Vol. 5, Iss. 1, p. 7-74.

${ }^{16}$ Richard J. Stiggins, "Student - Centered Classroom Assessment. Second Edition”, p. 1-521; Anthony J. Nitko and Susan Brookhart, Educational Assessment. Fifth Edition (New Jersey: Pearson Prentice Hall, 2007), p. 1-576.

${ }^{17}$ Richard J. Stiggins, "Student - Centered Classroom Assessment. Second Edition”, p. 1-521

${ }^{18}$ Paul Black \& Dylan Wiliam, "Assessment and Classroom Learning, Assessment in Education”, Abingdon: Mar 1998. Vol. 5, Iss. 1, p. 7-74

${ }^{19}$ Paul Black \& Dylan Wiliam, “Assessment and Classroom Learning, Assessment in Education”, Abingdon: Mar 1998. Vol. 5, Iss. 1, p. 7-74; Richard W. Puddy, et al. "Demonstrating support for the formative and summative assessment paradigm in a school-based intensive mental health program", Springer Science Business Media, Vol. 17, No. 2, 2008, p. 253-263.

${ }^{20}$ Richard J. Stiggins, "Student - Centered Classroom Assessment. Second Edition”, p. 1-521; Sattery, 1989; Harlen and James, 1997).
} 
targets and contribute significantly to students' achievements. ${ }^{21}$ Moreover, the nature of summative assessment, which is grading and judging the students, might undermine students' self-efficacy, particularly for the less-perform students. ${ }^{22}$

On the other hand, other scholars raised an issue of resources that has been used in constructing and administering both formative and summative assessment. ${ }^{23}$ Formative assessment tends to consume a greater time and effort of both teachers and students, not to mention the amount of funds spent in doing so. Both teachers and students should deal with the process of observing, understanding, and adjusting their learning condition in order to achieve better improvement. For teachers, it may involve hours of constructing assessment tasks, diagnosing students' abilities, and creating effective teaching methodologies. Similarly, students need an extensive amount of time to do the tasks and analyze their strengths and weaknesses as well as identifying their preference method of studying. ${ }^{24}$

The nature formative and summative assessment, as well as its roles, indicates that both assessments are important for the learning process. The results of both assessment types are often used as the basic sources to support learning conditions as well as improving learning achievements. ${ }^{25}$ For instance, the formative assessment result of a class can be an important starting point for teachers to tailor their teaching methodologies as well as identify students' necessities. Similarly, the summative assessment result can be used as a sample for the school authority and other stakeholders to evaluate students learning achievements in order to make decisions and impose policies. ${ }^{26}$ It can also be used as the basic information to provide certain supports which may contribute to the betterment of the learning process. ${ }^{27}$ More importantly, students can use their record of assessment to evaluate their strengths and weaknesses in order to improve their ability to achieve educational and vocational needs. ${ }^{28}$

In a broader context, formative and summative assessment are significant for learning process in the sense that its results can inform students, teachers, and decision makers to

\footnotetext{
${ }^{21}$ Anthony J. Nitko and Susan Brookhart, Educational Assessment. Fifth Edition (New Jersey: Pearson Prentice Hall, 2007), p. 1-576.

${ }^{22}$ Peter W. Airasian and Michael K. Russell, Classroom Assessment: Concepts and Applications. (New York: McGraw-Hill Higher Education, 2008), p. 1-412.

${ }^{23}$ G. Tindal, G \& D. Marston, 1990. Classroom-based assessment: evaluating instructional outcomes. Columbus, Ohio: Merrill, 1990.

${ }^{24}$ (Tindal and Martson, 1990).

${ }^{25}$ Richard J. Stiggins, "Student - Centered Classroom Assessment. Second Edition”, p. 1-521; Phye, 1997; Richard W. Puddy, et al. "Demonstrating support for the formative and summative assessment paradigm in a schoolbased intensive mental health program”, Springer Science Business Media, Vol. 17, No. 2, 2008, p. 253-263.

${ }^{26}$ Richard W. Puddy, et al. "Demonstrating support for the formative and summative assessment paradigm in a school-based intensive mental health program”, Springer Science Business Media, Vol. 17, No. 2, 2008, p. $253-263$.

${ }^{27}$ Richard J. Stiggins, "Student - Centered Classroom Assessment. Second Edition”, p. 1-521.

${ }^{28}$ Richard J. Stiggins, "Student - Centered Classroom...” p. 1-521.
} 
undertake certain decisions to create better learning process and conditions. In this regard, stiggins (1997) noted that assessment results can contribute to the betterment of learning process in three main levels: instructional level, instructional leadership/support level, and policy level. $^{29}$

\section{Taking the Key Principles of Assessment Policy Into Account}

In a broader sense, the key principles of curriculum and instructional process of assessment policy incorporates three significant areas of assessment: planning, assessing, and reporting. In this regard, the policy is intended to signify assessment as an integral process of (a) planning and designing the assessment and the curriculum, (b) assessing learning process and outcomes, and (c) reporting the learning outcomes to stakeholders, by which it may be used to review and evaluate the assessment for future development. ${ }^{30}$ Moreover, the process is perceived as an integral and cyclical process that is designed to enhance learning process and students' achievements.

In terms of planning, the assessment should be designed to provide sufficient raw input for teachers and other stakeholders to plan the curriculum as well as the learning process. Assessment result is regarded as a preliminary source of designing the curriculum as well as developing learning strategies. ${ }^{31}$ More importantly, in the assessment process, the assessment should be used as a means to monitor the progress of students learning and achievements. ${ }^{32}$ The monitoring effort should incorporate the use of different methods of assessment, and putting the assessment task in authentic contexts so that it contributes significantly to the betterment of students' future. ${ }^{33}$ Furthermore, the result of the assessment should be reported to the stakeholders in order to inform the learning outcomes and review the effectiveness of learning and teaching process as well as evaluate the suitability and effectiveness of the curriculum. ${ }^{34}$

\footnotetext{
${ }^{29}$ Richard J. Stiggins, "Student - Centered Classroom...", p. 1-521

30 Anthony J. Nitko and Susan Brookhart, Educational Assessment. Fifth Edition (New Jersey: Pearson Prentice Hall, 2007), p. 1-576; Stiggins, 1997; Butler and McMunn, 2006).

31 Anthony J. Nitko and Susan Brookhart, Educational Assessment. Fifth Edition (New Jersey: Pearson Prentice Hall, 2007), p. 1-576; Richard J. Stiggins, "Student - Centered Classroom Assessment. Second Edition”, p. 1-521.

32 Anthony J. Nitko and Susan Brookhart, Educational Assessment. Fifth Edition (New Jersey: Pearson Prentice Hall, 2007), p. 1-576; Paul Black \& Dylan Wiliam, “Assessment and Classroom Learning, Assessment in Education”, Abingdon: Mar 1998. Vol. 5, Iss. 1, p. 7-74.

${ }^{33}$ Anthony J. Nitko and Susan Brookhart, Educational Assessment. Fifth Edition (New Jersey: Pearson Prentice Hall, 2007), p. 1-576; Richard J. Stiggins, "Student - Centered Classroom Assessment. Second Edition”, p. 1-521; Phye, 1997).

34 Anthony J. Nitko and Susan Brookhart, Educational Assessment. Fifth Edition (New Jersey: Pearson Prentice Hall, 2007), p. 1-576; Richard J. Stiggins, "Student - Centered Classroom Assessment. Second Edition", p. 1-521; Richard W. Puddy, et al. "Demonstrating support for the formative and summative assessment paradigm in a schoolbased intensive mental health program”, Springer Science Business Media, Vol. 17, No. 2, 2008, p. 253-263.
} 
This paper will elaborate and discuss three main aspects of assessment policy: (a) assessment forms an integral part of planning, assessing, and reporting, (b) the use of assessment as a means to monitor the progress of student learning and achievement, (c) assessment as a tool to determine the effectiveness of teaching.

\section{Assessment Forms an Integral Part of Planning, Assessing, and Reporting}

The general principle of assessment in the assessment policy is that assessment is perceived as an inherent and inter-dependent process which contributes significantly to the effectiveness of teaching and learning. The process incorporates planning, assessing, and reporting which can be describe as cyclical and on-going process Diagram 1),

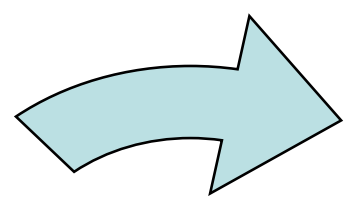

PLANNING

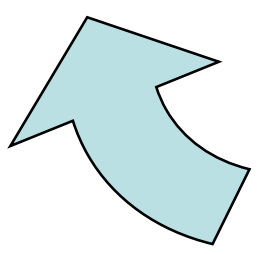

ASSESSING

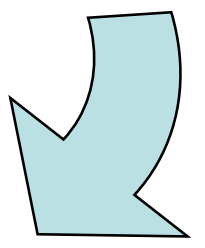

REPORTING

Diagram 1: Illustration of Assessment Cyclical Process (Adjusted from Harlen (2006 in Gardner, 2006, pp. 105) 'Assessment for learning as a cycle of events')

The process may start from gathering various information in order to plan the curriculum, teaching and learning process as well as assessment plan. Then, the assessment process runs in-line with the implementation of the agreed plan. The assessment process also incorporates some adjustment of the plan in response to the changing contexts occurred during the process of teaching and learning. Subsequently, the assessment result will be reported to stakeholders. The assessment result will be reviewed and evaluated in order to revise and develop a new plan. ${ }^{35}$

35 Anthony J. Nitko and Susan Brookhart, Educational Assessment. Fifth Edition (New Jersey: Pearson Prentice Hall, 2007), p. 1-576; W. Harlen, "The role of Assessment in developing motivation for learning", In J. Gardner (Ed.), Assessment and learning (London: Sage Publication, 2006), p. 61-80. 
Although the cyclical process described above has underlined some of the basic principles of a good quality assessment system, which is an on-going process of learning, there are some important aspects that need further concern. First, in the process of planning, teachers should also define the purpose of the assessment because the purpose of assessment may determine the types of assessment that will be administered. ${ }^{36}$ In general, formative purposes will require more informal types of assessment such as informal observation, homework, and pupil questions. In contrast, the summative purposes tend to use some structured and formal tests such as projects and paper pencil tests. ${ }^{37}$ Moreover, there should be a close link between the assessment and learning targets in order to improve the validity of the assessment procedure. ${ }^{38}$

Second, in both planning and assessing process, teachers need to take into account students' involvement. One form of involving students in the planning process is identifying their necessities and capabilities as well as accommodating their needs in the assessment plan. In the cyclical process above, this information can be obtained from the review of the assessment report or some other ways such as conducting a little survey on students' expectation or informal pre-test to understand students' pre-knowledge. ${ }^{39}$ In the assessment process, students' involvement can take form of student self assessment and peer assessment, even involving students to discuss the assessment criteria ${ }^{40}$.

Another important aspect that should be considered is moderation: "An interactive analysis of students' work by a group of teachers to qualify students understanding and increase teacher sensitivity to students' progress with difficult, complex concepts" .41 A good system of moderation can be used to enhance the reliability of summative assessment report (Heritage and Yeagley, n.d.). Furthermore, according to Wilson (2004 in Heritage and Yeagley, n.d.), moderation involves two important components: 'assessment moderation' and 'verification'. Assessment moderation focuses on judging students work by teachers

36 Anthony J. Nitko and Susan Brookhart, Educational Assessment. Fifth Edition (New Jersey: Pearson Prentice Hall, 2007), p. 1-576; Richard J. Stiggins, Student - Centered Classroom Assessment. Second Edition, (New Jersey: Merrill Prentice Hall, 1997), p. 1-521.

37 Richard J. Stiggins, "Student - Centered Classroom Assessment. Second Edition”, p. 1-521; Airaisian, 2005; Euguenia Peterson \& M. Siadat, "Combination of formative and summative assessment instruments in elementary algebra classes: A prescription for success", Journal of Applied Research in the Community College, (Stillwater : New Forums Press), 2009), p. 92-102.

${ }^{38}$ Anthony J. Nitko and Susan Brookhart, Educational Assessment. Fifth Edition (New Jersey: Pearson Prentice Hall, 2007), p. 1-576.

${ }^{39}$ Anthony J. Nitko and Susan Brookhart, Educational Assessment. Fifth Edition (New Jersey: Pearson Prentice Hall, 2007), p. 1-576; Richard J. Stiggins, "Student - Centered Classroom Assessment. Second Edition”, p. 1-521.

40 Richard J. Stiggins, "Student - Centered Classroom Assessment. Second Edition”, p. 1-521; Peter W. Airasian and Michael K. Russell, Classroom Assessment: Concepts and Applications. (New York: McGraw-Hill Higher Education, 2008), p. 1-412

${ }^{41}$ L. Malone, K. Long \& L. D. Lucchi, “All things in moderation”, Science and Children. Research Library, 2004 p. $41,5$. 
through moderation group, while verification is mainly undertaken by external experts or certain statistical technique (Heritage and Yeagley, n.d.).

\section{Assessment Monitors the Progress of Student Learning and Achievement}

The main purpose of this key principle is using assessment as a means to monitor learning process and students' achievement. To achieve this purpose, both formative and summative assessment should be employed during the process of learning; with the emphasis on formative. It is mainly because the nature of formative assessment is more suitable to the purpose of monitoring students' learning and achievement progress. It emphasizes on progress and achievement rather than failure and defeat. ${ }^{42}$

In support for the above policy, some of the key characteristics of formative assessment proposed by Nitko and Brookhart (2007) should be employed in the assessment process. First, a formal or non formal pre-test should be administered before a unit of study is carried out. The pre-test is intended to adjust the assessment plan as well as the instruction. Moreover, the pre-test also helps teachers to analyze which students need more practice. Second, teachers should continually revise their instruction in regard to students' performance. More importantly, teachers should be reflective to the effectiveness of their own teaching practice. Third, teachers are obliged to provide a constructive feedback for students, particularly about strengths and areas that need improvement. In addition, teachers can facilitate peer tutoring which matches less perform students with high perform students. ${ }^{43}$

To some extent, the policy seems to undermine the role of summative assessment. Yet, it is inevitable that formative assessment has a substantial contribution to enhance learning process. However, summative assessment still has its own place in teaching and learning. It is true that some research also suggested that the nature of summative assessment, which is comparing students and grading them, might have some negative impact such as undermining students self-efficacy. ${ }^{44}$ However, the fact that it provides a summative result of students' achievement is unavoidable. In fact, it can be an effective summary of students' achievement in order to provide report for the stakeholders such as parents, employers, further higher educational institution, and students. ${ }^{45}$

42 Richard J. Stiggins, Student - Centered Classroom Assessment. Second Edition, (New Jersey: Merrill Prentice Hall, 1997), p. 1-521.

43 Anthony J. Nitko and Susan Brookhart, Educational Assessment. Fifth Edition (New Jersey: Pearson Prentice Hall, 2007), p. 1-576.

44 Paul Black \& Dylan Wiliam, “Assessment and Classroom Learning, Assessment in Education”, Abingdon: Mar 1998. Vol. 5, Iss. 1, p. 7-74; Peter W. Airasian and Michael K. Russell, Classroom Assessment: Concepts and Applications. (New York: McGraw-Hill Higher Education, 2008), p. 1-412.

${ }^{45}$ W. Harlen, "The role of Assessment in developing motivation for learning”, In J. Gardner (Ed.), Assessment and learning (London: Sage Publication, 2006), p. 61-80.; Earl, 2003). 
Furthermore, some research suggested that summative assessment can be used to help further learning, in terms of using it as formative purposes. ${ }^{46}$ A research by Black et al. (2003 in Gardner, 2006), for instance, showed that teachers can modify the summative tests into formative purposes in order to help students in the learning process. The modification incorporates three main ways. First, preparing students for test by helping them screening past tests and identifying some areas that they have lack of understanding. This may help them to understand their weaknesses as well as focusing more effort to nullify the weaknesses. Second, asking students to develop test questions as well as the marking schemes. Third, requiring teachers to analyze the test result diagnostically and involving students to do the marking through peer assessment. ${ }^{47}$

Therefore, it is important to consider assessment as an integral part of learning that is meant to help student to achieve learning objectives. More importantly, assessment should be understood as an on-going process of learning. ${ }^{48}$ It should also be functioned as an instructional tool to promote learning, not to solely for evaluation and grade assignment. ${ }^{49}$

One way to achieve this purpose is by Setting up a comprehensive system of teaching and learning such as mastery learning program. ${ }^{50}$ The program involves providing feedback to students upon their achievements in relation to the expected level of achievement (the mastery level). The feedback is given continuously and the students are provided with an opportunity to discuss about the gap between their current level and the mastery level, including the way how to close the gap. ${ }^{51}$ It is also important to note that the effect of feedback can be positive if it is used to guide students toward improvement. Students should understand two important levels: reference level (the goal of their learning) and the level of their understanding. ${ }^{52}$

The above discussion, to some extent, has brought the notion which presumes that assessment is a matter of providing feedback to students. ${ }^{53}$ Thus, assessment result could be a meaningful tool to enhance learning, regardless summative or formative, if it is interpreted in such a way that provide constructive feedback for students to close the gap

${ }^{46}$ (Maxwell, 2004; Black and Wiliam, 2006; W. Harlen, "The role of Assessment in developing motivation for learning”, In J. Gardner (Ed.), Assessment and learning (London: Sage Publication, 2006), p. 61-80.

${ }^{47}$ J. Gardner, Assessment and learning. (J. Gardner, Ed.). London: Sage Publication, 2006

${ }^{48}$ W. Harlen, "The role of Assessment in developing motivation for learning”, In J. Gardner (Ed.), Assessment and learning, (London: Sage Publication, 2006), p. 61-80; Earl, 2003; Shepard, 2000 in Cappuis and Stiggins, 2002; crooks, 2001).

${ }^{49}$ S. Chappuis \& R. J. Stiggins, Classroom assessment for learning. Educational Leadership. Vol. 60, 2002, Iss. 1

${ }^{50} \mathrm{~W}$. Harlen, The role of Assessment in developing motivation for learning. In J. Gardner (Ed.), Assessment and learning, (London: Sage Publication, 2006), p. 61-80.

${ }^{51}$ (Black and Wiliam, 2006).

${ }^{52}$ D. Satterly, Assessment in schools (2nd ed.). Oxford, UK ; New York, NY, USA: B. Blackwell, 1989.

${ }^{53}$ John A. Hattie, Formative and summative interpretations of assessment information. Auckland, (New Zealand: The University of Auckland, 2003). 
between their level of mastery and the aspired goals or the learning targets. ${ }^{54}$ Moreover, both formative and summative assessment are significant for learning process in the sense that its result can inform students, teachers, and decision makers to undertake certain decisions that will create better learning process and conditions.

\section{Assessment as a Means to Determine the Effectiveness of Teaching}

Apart from its contribution to enhance learning, assessment is also used as a tool to determine the effectiveness of teaching. At least, there are two important aspects of assessment that can be used to evaluate the effectiveness of teaching. First, assessment result is used to determine and evaluate the on-going teaching strategies in regard to the changing of learning environment, in terms of students' needs and capabilities. Second, the summative result of assessment can also be used to judge the overall teaching process, particularly when the targets are not achieved.

In line with the above conception, it is important to consider some of the points noted by Nitko and Brookhart concerning assessment that can be used to make judgment about teaching. Nitko and Brookhart (2007) stated that using some information resulted from assessment, teachers can make three different judgments about their teaching: before, during, and after the teaching/learning process. First, in the beginning or before the teaching process starts, the judgment is about planning the learning process, the strategies that could be used, and materials that should be included in the curriculum as well as deciding the learning target. In this case, previous assessment result will be beneficial to consider. ${ }^{55}$

Second, during the process of teaching, teachers should also make some judgments in order to determine whether the lessons or the activities that being carried on are going well or not. This will require the teachers to diagnose the learning process in order to adjust the lessons if they are not suitable with students' needs and capabilities as well as providing feedback for students' performance. More importantly, the assessment result will help the teachers to determine the effectiveness of their teaching so that they will feel confident to continue the process to the next lessons or activities. ${ }^{56}$

Third, after the teaching process, assessment result can be used to make report about students' achievements to other stakeholders such as parents, and school authority. Furthermore, the result can also be used to analyze the effectiveness of the teaching. It can

54 John A. Hattie, Formative and summative interpretations of assessment information. Auckland, (New Zealand: The University of Auckland, 2003)

${ }^{55}$ Anthony J. Nitko and Susan Brookhart, Educational Assessment. Fifth Edition (New Jersey: Pearson Prentice Hall, 2007), p. 1-576.

${ }^{56}$ Anthony J. Nitko and Susan Brookhart, Educational Assessment, p. 1-576. 
be obtained from reviewing students' achievements, students' perceptions on the teaching process, and the review of some informal observation summary. ${ }^{57}$

\section{CONCLUSION}

It is understandable that formative and summative assessment are different in nature, in terms of the purpose of assessment, the time of assessment, the use of assessment information, and the type of assessment. In regard to this different nature, some people are in favor with formative assessment rather than summative assessment. The literature also suggested that there should be more focus on formative assessment. However, both formative and summative assessment are two important aspects in learning process. Both assessment types serve and help the learning process in different ways. Therefore, it is important to use formative and summative assessment in proportion with regard to its nature and role.

Assessment policy has to underline most of the important features of a good assessment policy, in terms of comprehensiveness. In the curriculum and instructional process, this policy should propose a good framework of assessment cycle which perceives assessment system as a cyclical process incorporates planning, assessing, and reporting. Moreover, the policy should also consider the importance of formative and summative purposes of assessment and its contribution to learning and teaching as well as taking into account students' contribution to the process of assessment. Furthermore, assessment should be considered as an important factor that may determine the effectiveness of teaching as well as the curriculum.

In addition, assessment policy should provide enough information for the readers to understand the contexts as well as the details. Therefore, it is important for the school authority to provide documents which provide sufficient background and more explanation of the key principles mentioned in the policy. The school authority might need to set up and integrate the system of moderation in the assessment policy. Moreover, the policy may need a section which briefly explain how the policy is developed and who has been involved in the process.

\section{REFERENCES}

Airasian, P. and Russell, M. 2008. Classroom assessment: concepts and applications. New York: McGraw-Hill Higher Education.

${ }^{57}$ Anthony J. Nitko and Susan Brookhart, Educational Assessment, p. 1-576. 
Boyle, B., \& Charles, Marie. 2013. Formative assessment for teaching \& learning. Los Angeles, California SAGE.

Black, P., \& Wiliam, D. 1998. Assessment and classroom learning, Assessment in Education. Abingdon: Mar 1998. Vol. 5, Iss. 1.

Brown, G., Bull, J., \& Pendlebury, M. 1997. Assessing student learning in higher education. London; New York: Routledge.

Butler, S. and McMunn, D. 2006. A teacher's guide to classroom assessment: Understanding and using assessment to improve student learning. San Francisco. Jossey-Bass.

Chappuis S., \& Stiggins, R. J. 2002. Classroom assessment for learning. Educational Leadership. Vol. 60. Iss. 1.

Earl, Lorna. 2003. Assessment as Learning: Using Classroom Assessment to Maximise Student Learning. Thousand Oaks, CA, Corwin Press.

Ecclestone, K. 2010. Transforming Formative Assessment In Lifelong Learning. Maidenhead: McGraw-Hill Education.

Gardner, J. 2006. Assessment and learning. (J. Gardner, Ed.). London: Sage Publication.

Hanna, G. S., \& Dettmer, P. 2004. Assessment for effective teaching: using contextadaptive planning. Boston: Pearson A and B.

Harlen, W. 2006. The role of Assessment in developing motivation for learning. In J. Gardner (Ed.), Assessment and learning (pp. 61-80). London: Sage Publication.

Harlen, W., \& James, M. 1997. Assessment and learning: Differences and relationships between formative and summative assessment. Assessment in Education. Nov

Hattie, J. 2003. Formative and summative interpretations of assessment information. Auckland, New Zealand: The University of Auckland.

Heritage, M., \& Yeagley, R. (n. d.). Data Use and School Improvement: challenges and Prospects. Educational Research and Development Centers Program, PR/Award Number R305B960002.

Malone, L., Long, K., \& Lucchi, L. D. 2004. All things in moderation. Science and Children. 41, 5; Research Library.

Nitko, A., \& Brookhart, S. 2007. Educational Assessment. Fifth Edition. New Jersey. Pearson Prentice Hall.

Peterson, E., \& Siadat, M., V. 2009. Combination of formative and summative assessment instruments in elementary algebra classes: A prescription for success. Journal of Applied Research in the Community College. Stillwater : New Forums Press.

Phye, G. D. 1997. Handbook of classroom assessment: learning, achievement, and adjustment. San Diego: Academic Press. 
Puddy, R., W. et al. 2008. Demonstrating support for the formative and summative assessment paradigm in a school-based intensive mental health program. Springer Science Business Media. 17,

Satterly, D. 1989. Assessment in schools (2nd ed.). Oxford, UK ; New York, NY, USA: B. Blackwell.

Spinelli, C. G. 2006. Classroom assessment for students in special and general education (2nd ed.). Upper Saddle River, N.J.: Pearson/Merrill/Prentice Hall.

Stiggins, R. 1997. Student - Centered Classroom Assessment. Second Edition. New Jersey. Merrill Prentice Hall.

Tindal, G., \& Marston, D. 1990. Classroom-based assessment: evaluating instructional outcomes. Columbus, Ohio: Merrill. 